\title{
Thirty-day $\beta$-hydroxy- $\beta$-methylbutyrate supplementation with a controlled diet does not alter the morphological and morphometric characteristics of the rat diaphragm muscle
}

\section{A suplementação $\beta$-hidroxi- $\beta$-metilbutirato por trinta \\ dias e com dieta controlada não altera as \\ características morfológicas e morfométricas \\ do músculo diafragma de ratos}

\author{
Cleuber Rodrigo de Souza BUENO1 1 D0000-0002-8963-8793

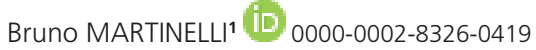 \\ Gabriele Candido BERNARDO ${ }^{1}$ (D) 0000-0002-3916-1771

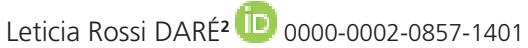 \\ Jesus Carlos ANDREO3 ${ }^{3}$ (D) 0000-0001-7227-1908 \\ Geraldo Marco ROSA JUNIOR' ${ }^{\text {iD }}$ 0000-0003-1787-3396
}

A B S TR A C T

\section{Objective}

To evaluate the $\beta$-hydroxy- $\beta$-methylbutyrate supplementation influence on the morphological and morphometric characteristics of the diaphragm muscle of rats and verify whether there are sex differences.

\footnotetext{
1 Universidade do Sagrado Coração, Centro de Ciências da Saúde e Programa de Pós-Graduação, Departamento de Biologia e Fisioterapia. R. Irmã Arminda, 10-50, Jardim Brasil, 17011-160, Bauru, SP, Brasil. Correspondence to: B MARTINELLI. E-mail: <internetbruno@yahoo.com.br>.

2 Universidade Federal do Pampa, Centro de Ciências da Saúde, Departamento de Biologia. Uruguaiana, RS, Brasil.

${ }^{3}$ Universidade de São Paulo, Faculdade de Odontologia, Departamento de Ciências Biológicas. Bauru, SP, Brasil.

Article based on the master's thesis by LR DARÉ, entitled "Efeito do $\beta$-hidroxi- $\beta$-metilbutirato sobre os músculos da mastigação e desenvolvimento e crescimento craniofacial de ratos”. Universidade de São Paulo; 2013.
}

\section{How to cite this article}

Bueno CRS, Martinelli B, Bernardo GC, Daré LR, Andreo JC, Rosa Junior GM. Thirty-day $\beta$-hydroxy- $\beta$-methylbutyrate supplementation with a controlled diet does not alter the morphological and morphometric characteristics of the rat diaphragm muscle. Rev Nutr. 2019;32:e180235. http://dx.doi.org/10.1590/1678-9865201932e180235 


\section{Methods}

Experimental study with 48 Wistar rats (24 of each sex) divided into 3 groups: Control Group: in which a daily diet with saline solution was offered; Experimental Group: the same amount of food from the Control group consumed in the previous day and $0.3 \mathrm{~g} / \mathrm{kg}$ of $\beta$-hydroxy- $\beta$-methylbutyrate; Ad libitum Experimental Group: ad libitum feeding with the same dose of the supplement. The analysis consisted of histomorphometry and classification in diaphragm muscle fiber area bands. The procedures occurred 30 days after the start of the experiment. Data were analyzed using the one-way ANOVA and Tukey tests $(p<0.05)$.

\section{Results}

There was no increase in the cross-sectional area of the diaphragm muscle fibers with the supplementation protocol employed and a similar histological pattern in both sexes. No significant changes were observed in muscle fiber size ranges in the supplemented groups, suggesting that there was no hypertrophy of muscle fibers.

\section{Conclusion}

This study suggests that $\beta$-hydroxy- $\beta$-methylbutyrate supplementation does not cause changes in the morphological and morphometric characteristics of the diaphragm muscle, regardless of sex.

Keywords: Diaphragm. Histology. Rats Wistar. Supplementary feeding.

\section{R E S U M O}

\section{Objetivo}

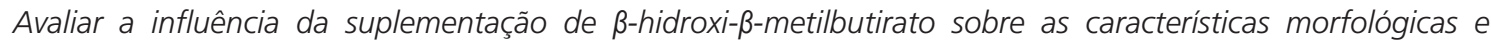
morfométricas do músculo diafragma de ratos e se existe diferenças entre os sexos.

\section{Métodos}

Estudo experimental com 48 ratos Wistar (24 de cada sexo) divididos em 3 grupos: Grupo Controle, no qual foi ofertada dieta diária com soro fisiológico; Grupo Experimental, ofertada 0,3g/kg de $\beta$-hidroxi- $\beta$-metilbutirato e mesma quantidade de alimentos do Grupo Controle consumida no dia anterior; Grupo Experimental Ad libitum com mesma dose do suplemento, porém com alimentação Ad libitum. A análise foi feita através da histomorfometria e classificação em faixas de área das fibras musculares após 30 dias do início do experimento. Os dados foram analisados pelos testes Anova one-way e Tukey $(p<0,05)$.

\section{Resultados}

Não foi observado aumento da área de seç̧ão transversal das fibras do músculo diafragma com o protocolo de suplementação utilizado e no padrão histológico em ambos os sexos. Não foram observadas mudanças significativas nas faixas de tamanho de fibras musculares nos grupos suplementados, sugerindo que não houve hipertrofia das fibras musculares.

\section{Conclusão}

A suplementação com $\beta$-hidroxi- $\beta$-metilbutirato não provoca alterações nas características morfológicas e morfo-métricas do músculo diafragma, independente do sexo.

Palavras-chave: Diafragma. Histologia. Ratos Wistar. Suplementação alimentar.

\section{NTRODUCTION}

The use of dietary supplements by humans is growing in popularity [1] because it provides ergogenic benefits, especially to sportspersons and athletes that are seeking to improve their physical performance. Also, these substances may assist in the treatment of degenerative chronic diseases [2]. However, it is crucial to know the real effects of dietary supplements so that individual consumers can benefit from them, especially because the use of anabolic and dietary supplements can also be harmful to health [3].

Among several dietary supplements that promise positive gains, $\beta$-hydroxy- $\beta$-methylbutyrate (HMB) has been indicated as a promising substance [4]. This is a compound derived from amino 
acid metabolism L-leucine and provides protein anabolic effects [5]. Positive evidence on muscle metabolism has been reported to act in decreasing muscle fiber catabolism [6]. Also, detailed knowledge of these substances' effects on various human tissues is crucial. In a study of more than 200 dietary supplements, only creatine and HMB provided the desired effects [7]. HMB suppresses the increase of creatine phosphokinase caused by exercise and affects plasma urea and urinary nitrogen [8]. There are changes even in cardiovascular markers, especially in cholesterol biosynthesis. HMB lowers total cholesterol (5.8\%), increases low density lipoproteins cholesterol (7.3\%), and lowers systolic blood pressure $(4.4 \mathrm{mmHg})$ [9]. There is evidence that HMB improves immune function. HMB supplementation is safe and the general hypothesis is that HMB is metabolized to HMG-CoA in muscle, mammary, and certain immune cells. This supplementation may provide a saturated source of cytosolic HMG-CoA by cholesterol synthesis and, in turn, it allows for maximum cell and functional growth $[9,10]$.

Also, HMB has been identified as an auxiliary agent in the treatment of diseases with exacerbated proteolytic activity, such as cancer [11], acquired immunodeficiency syndrome [12], chronic degenerative diseases [13], and atrophy caused by disuse [14]. This supplement can also increase muscle mass, strength, and endurance, factors that are explored by exercise practitioners [15]. However, studies investigating the effects of HMB supplementation on muscles that ate not directly related to physical exercises are rare. Even respiratory muscles may benefit from this supplementation, specifically the diaphragm, since there are reports of positive effects of HMB as an adjunctive treatment in sepsis and respiratory dysfunction [16].

Regarding the histological aspect, the effects of $\mathrm{HMB}$ on the area and the distribution of muscle fibers are still scarce, especially in a comparison between sexes. Thus, this analysis is significant, since the effect can show the differences between them. Female rats can present hormonal interference. Another study [17] found that female rats were more sensitive to steroid anabolic use because of lower endogenous levels compared to males.

Therefore, the objective of this study was to analyze the influence of HMB on morphological and morphometric characteristics of the diaphragm muscle and compare its effects between male and female animals.

\section{METHODS}

This study was approved by the Ethics Committee of the Universidade de São Paulo (USP, University of São Paulo), protocol $n^{\circ}$ 009/2011. The sample consisted of 48 Wistar rats (24 males and 24 females), 60 days old, with no restrictions on movement, respecting 12-hour light cycles and the average temperature of $24^{\circ} \mathrm{C}$.

The animals were divided into three groups, two experimental and a control one. The Experimental Group (EG) received $0.3 \mathrm{~g} / \mathrm{kg}$ of $\mathrm{HMB}$ daily by gavage, in a controlled diet; the $\mathrm{Ad}$ libitum Experimental Group (AEG) received $0.3 \mathrm{~g} / \mathrm{kg}$ of $\mathrm{HMB}$ daily by gavage and ad libitum feeding; and the Control Group (CG) received the saline solution as a placebo. The EG consumed the same amount of food as the control group did the day before. The randomization was performed by the laboratory staff and the experimental procedure lasted 30 days.

Animals were euthanized with an excessive anesthetic injection (Xylazine Hydrochloride combined with Ketamine Hydrochloride) intraperitoneally, 30 days after the start of the experiment. The diaphragm muscles of all animals were removed through a horizontal incision in the abdomen, allowing total muscle dissection and vision. 
For the histological treatment, the tendon portion of the diaphragm muscle was removed and correctly arranged for a cross-section.

After that, the muscle was wrapped in $\operatorname{Tissue-Tek}^{\circledR}$ (O.C.T., Sakura Finetek, Torrance, USA) inclusion medium that is suitable for a fast-freezing protocol in liquid nitrogen. Histological sections were performed on a cryostat at $-20^{\circ} \mathrm{C}$ (Leica ${ }^{\circledR}, C M$ 1850, Nussloch, Germany) and subsequent histological slides were stained with Hematoxylin and Eosin (HE).

Observations and muscle morphometries were conducted using the Image Pro-Plus ${ }^{\circledR}$ 6.2, Image Capture and Analysis (Media Cybernetics, Bethesda, MD, USA) computer software programs, connected to an optical microscope (Olympus ${ }^{\circledR}, \mathrm{BX}-50$, Tokyo, Japan) with a photographic feature (Olympus ${ }^{\circledR}$ DP-71, Tokyo, Japan). Also, the cross-sectional morphometry of 220 fibers of each animal was performed.

Another morphometric analysis was performed by examining the frequency of muscle fiber distribution in five increasing cross-sectional area size ranges. The smallest and the largest muscle fibers found among all groups were verified in the morphometric analysis of males and females. Then, the interval between these measurements was calculated and the resulting value was divided by five, thus making five ranges of muscle fiber size. Finally, the muscle fibers of all animals were analyzed and classified in their proper frequency range, respectively.

Figure 1 shows the skeletal striated musculature in a cross-section with the representation for the calculation of the morphometry of a muscle fiber. The values are automatically displayed by the software.

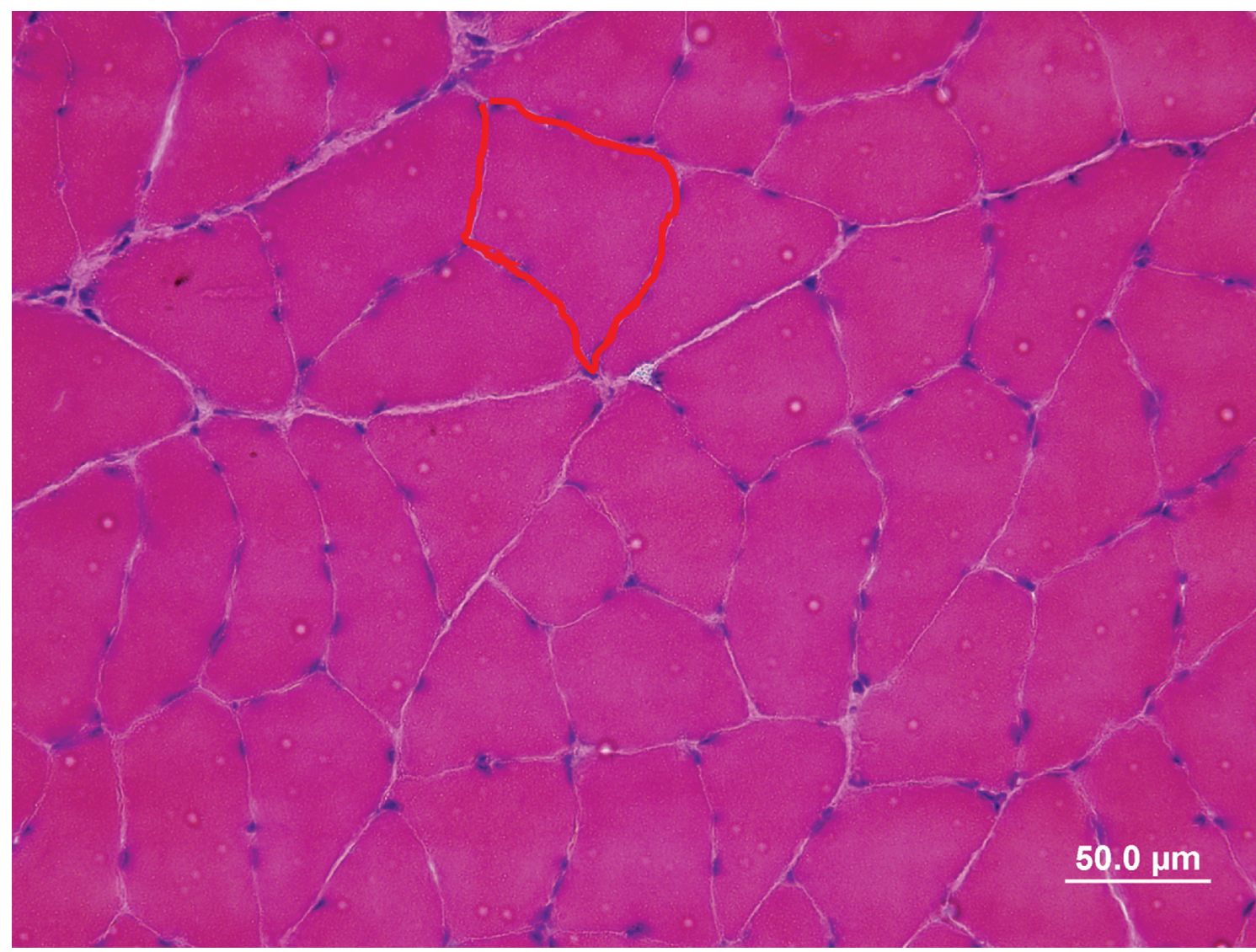

Figure 1. Illustration of skeletal striated muscle fiber stained with Hematoxylin and Eosin (HE) - histological slide, cross-section. 
Data are presented as mean \pm Standard Deviation. The one-way ANOVA test was applied for comparison. The Tukey's test, a posteriori complementary one, with a significance level of $p \leq 0.05$ was also applied using the SPSS ${ }^{\circledR}$ Software version 20 (IBM ${ }^{\circledR}, N Y$, USA).

\section{RES U L T S}

This study aimed to identify a possible influence of $\mathrm{HMB}$ on diaphragm muscles and to verify whether there were sex differences.

Regarding histological observations, the cross-section of the muscle fibers of both male and female animals were similar and no morphological differences were observed between the groups.

Also, characteristics such as polygonal fibers, peripheral nuclei, normal fascicular pattern, and perimysium and endomysium delimiting each fascicle and muscle fiber, respectively, were evidenced in the groups, which demonstrated the normal morphology of the skeletal muscle tissue.

Regarding the morphometric analyses, the results related to the cross-sectional area of the diaphragm muscle showed no significant differences between the non-supplemented group and the experimental groups supplemented with $\mathrm{HMB}$, including in the comparison between sexes. This indicates there was no increase in the cross-sectional area of the diaphragm muscle fibers with the supplementation protocol used in the study. Likewise, no statistically significant differences were observed between the experimental groups, EG vs AEG (Table 1).

Table 1. Comparison of the cross-sectional area $\left(\mu \mathrm{m}^{2}\right)$ of the diaphragm muscle between supplementation and sex groups.

\begin{tabular}{|c|c|c|c|c|c|c|}
\hline \multirow{3}{*}{ Groups } & \multicolumn{6}{|c|}{ Results } \\
\hline & \multicolumn{3}{|c|}{ Male } & \multicolumn{3}{|c|}{ Female } \\
\hline & M & & SD & M & & SD \\
\hline$C G$ & 1244.01 & \pm & $115.17^{a}$ & 1226.76 & \pm & $158.76^{a}$ \\
\hline EG & 1381.45 & \pm & $282.04^{a}$ & 1279.96 & \pm & $170.82^{\mathrm{a}}$ \\
\hline$A E G$ & 1289.93 & \pm & $314.62^{a}$ & 1259.01 & \pm & $82.01^{a}$ \\
\hline
\end{tabular}

Note: Mean (M) and Standard Deviation (SD) values; ${ }^{a}$ Significant intra-group statistical difference $(p>0.05)$, by Analysis of Variance (ANOVA), followed by Tukey's Test; CG: Control Group; EG: Experimental Group; AEG: Ad libitium Experimental Group.
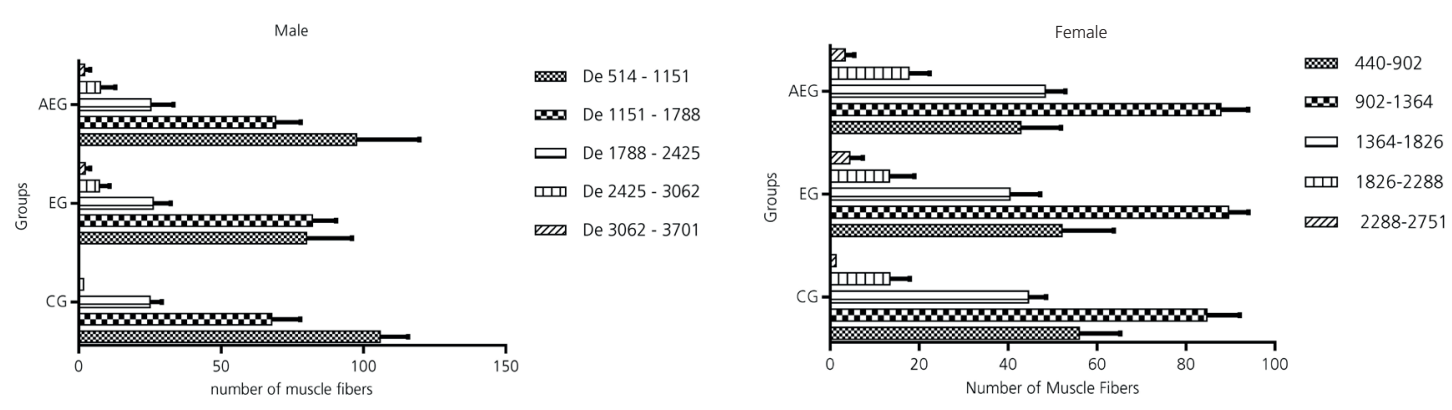

Figure 2. Frequency of muscle fiber area distribution according to sex.

Note: CG: Control Group; EG: Experimental Group; AEG: Ad libitium Experimental Group. 
Regarding the muscle fibers frequency of distribution, it was possible to verify that males presented larger bands of muscle fiber area compared to females. There were no changes with significant differences in the frequency distribution of muscle fibers in the supplemented groups, which suggests no muscle fiber hypertrophy in the experimental groups. Only subtle changes were observed in both sexes (Figure 2). There was no replacement or loss of animals during the study.

\section{DISCUSSION}

This study aimed to analyze the influence of HMB supplementation on the morphological and morphometric characteristics of rat diaphragm muscle under normal conditions and whether there was a similarity between males and females. Data analysis showed that HMB did not alter the histological and morphometric parameters of the muscle fiber area and frequency of distribution. Also, HMB did not have a considerable effect on males and females.

On the one hand, several studies have shown positive changes with the use of HMB in proteolytic situations mediated by decreased proteasome activity and protein degradation [18], as well as significant effects by protein synthesis pathway in stimulus situations, such as physical exercise [19].

On the other hand, data collected in this study suggests that under normal conditions, the HMB does not present a significant action in the morphological level. In another study conducted by this group of researchers with animals under normal conditions, no significant morphological and morphometric changes caused by HMB were found in the masseter and digastric muscles [20].

Supinski and Callahan [16] evidenced that HMB did not alter the strength of the diaphragm muscle under normal conditions, but the sepsis muscle that was supplemented with HMB was able to significantly increase muscle strength capacity. Sepsis may induce diaphragmatic weakness and HMB administration significantly attenuated diaphragmatic weakness, preserving muscle strength. Thus, this finding corroborates the evidence that HMB acts in a significant way in specific situations. Especially in this clinical situation of infection, in which patients may be unable to maintain their ventilatory function and need invasive mechanical support that leads to increased mortality, systemic complications, and higher health expenses.

It was possible to observe, in both sexes of the group that received the controlled diet, a tendency to present larger areas of muscle fibers compared to the group that received food at will. A study conducted by Wheatley et al. [21] tested various HMB concentrations and the authors observed that under the condition of high $\mathrm{HMB}$ concentrations reaching high amino acid levels in the bloodstream, no additive effects were identified compared to lower concentrations, showing that high HMB doses may be ineffective. Dietary intake increases protein-independent synthesis in the muscle [22] and amino acid levels in the bloodstream. Thus, under conditions of ad libitum feeding, such as in the AEG group, the action of HMB may have been limited by high amino acid concentrations. In situations in which feeding was restricted, HMB could have shown more positive results, though. Few studies analyzed the effects of $\mathrm{HMB}$ on the diaphragm muscle under normal conditions, mainly investigating both sexes. Females are often scarcely used for experimental studies because of hormonal interference. In the case of the diaphragm muscle, this is the first experimental study investigating the effect of HMB on females and whether their test results are similar to their male 
counterparts'. Under normal conditions, it was observed similar results between sexes, histological pattern, area, and distribution of muscle fibers.

It would be interesting to conduct future studies to analyze the effects on both sexes under proteolytic conditions, such as the use of invasive ventilatory support and protein synthesis in physical exercise. Also, to clarify whether there is a direct relationship between the amount of food intake and HMB performance.

\section{CONCLUSION}

Thus, under normal conditions, HMB supplementation does not cause changes in the morphological and morphometric characteristics of the diaphragm muscle, regardless of sex, which suggests that its use does not influence diaphragm muscle activity.

\section{CONTRIBUTORS}

CRS BUENO contributed to conception, design, analysis, interpretation, and approval. B MARTINELLI contributed to interpretation, review, and approval. GC BERNARDO contributed to drafting. LR DARÉ contributed to conception, design, drafting, collection, interpretation, and approval of the final version. JC ANDREO contributed to conception, design, analysis, and approval of the final version. GM ROSA JUNIOR contributed to conception, design, analysis, interpretation, review, and approval of the final version.

\section{REFERENCES}

1. Kennedy ET, Luo H, Houser RF. Dietary supplement use pattern of U.S. adult population in the 2007-2008 National Health and Nutrition Examination Survey (NHANES). Ecol Food Nutr. 2013;52(1):76-84.

2. Malafarina V, Uriz-Otano F, Iniesta R, Gil-Guerrero L. Effectiveness of nutritional supplementation on muscle mass in treatment of sarcopenia in old age: A systematic review. J Am Med Dir Assoc. 2013;14(1):10-7.

3. Li N, Hauser R, Holford T, Zhu Y, Zhang Y, Bassig BA, et al. Muscle-building supplement use and increased risk of testicular germ cell cancer in men from Connecticut and Massachusetts. Br J Cancer. 2015;112(7):1247-50.

4. Wilson JM, Fitschen PJ, Campbell B, Wilson GJW, Zanchi N, Taylor L, et al. International Society of Sports Nutrition Position Stand: beta-hydroxy-beta-methylbutyrate (HMB). J Int Soc Sports Nutr. 2013;10(6):1-14.

5. Wilkinson DJ, Hossain T, Hill DS, Phillips BE, Crossland H, Williams J, et al. Effects of leucine and its metabolite $\beta$-hydroxy- $\beta$-methylbutyrate on human skeletal muscle protein metabolism. J Physiol. 2013;591(11):2911-23.

6. Always SE, Pereira SL, Edens NK, Hao Y, Bennett BT. $\beta$-Hydroxy- $\beta$-methylbutyrate (HMB) enhances the proliferation of satellite cells in fast muscles of aged rats during recovery from disuse atrophy. Exp Gerontol. 2013;48(9):973-84.

7. Nissen SL, Sharp RL. Effect of dietary supplements on lean mass and strength gains with resistance exercise: A meta-analysis. J Appl Physiol. 2003;94(2):651-9.

8. Jówko E, Ostaszewski P, Jank M, Zieniewicz A, Wilszack J, Nissen S. Creatine and $\beta$-hydroxy $\beta$-methylbutyrate (HMB) additively increase lean body mass and strength during a weight training program. Nutrition. 2001;17(7-8):558-66.

9. Nissen S, Sharp RL, Panton L, Vukovich M, Trappe S, Fuller Junior JC. Beta-hydroxy-beta-methylbutyrate (HMB) supplementation in humans is safe and may decrease cardiovascular risk factors. J Nutr. 2000;130(8):1937-45.

10. Nissen $S$, Abumrad NN. Nutritional role of the leucine metabolite $\beta$-hydroxy- $\beta$-methylbutyrate (HMB). J Nutr Biochem. 1997;8:300-11. 
11. Mirza KA, Pereira SL, Voss AC, Tisdale MJ. Comparison of the anticatabolic effects of leucine and Ca- $\beta$-hydroxy- $\beta$-methylbutyrate in experimental models of cancer cachexia. Nutrition. 2014;30(7-8):807-13.

12. Fitschen PJ, Wilson GJ, Wilson JM, Wilund KR. Efficacy of $\beta$-hydroxy- $\beta$-methylbutyrate supplementation in elderly and clinical populations. Nutrition. 2013;29(1):29-36.

13. Armstrong DG, Hanft JR, Driver VR, Smith APS, Lazaro-Martinez JL, Reyzelman AM. Effect of oral nutritional supplementation on wound healing in diabetic foot ulcers: A prospective randomized controlled trial. Diabet Med. 2014;31(9):1069-77.

14. Wu H, Xia Y, Jiang J, Du H, Guo X, Liu X, et al. Effect of beta-hydroxy-beta-methylbutyrate supplementation on muscle loss in older adults: A systematic review and meta-analysis. Arch Gerontol Geriatr. 2015;61(2):168-75.

15. Wilson JM, Lowery RP, Joy JM, Andersen JC, Wilson SMC, Stout JR, et al. The effects of 12 weeks of beta-hydroxy-beta-methylbutyrate free acid supplementation on muscle mass, strength, and power in resistance-trained individuals: A randomized, double-blind, placebo-controlled study. Eur J Appl Physiol. 2014;114(6):1217-27.

16. Supinski GS, Callahan LA. $\beta$-hydroxy- $\beta$-methylbutyrate $(\mathrm{HMB})$ prevents sepsis-induced diaphragm dysfunction in mice. Respir Physiol Neurobiol. 2014;196(1):63-8.

17. Gebhardt A, Pancherz H. The effect of anabolic steroids on mandibular growth. Am J Orthod Dentofacial Orthop. 2003;123(4):435-40

18. Hao Y, Jackson JR, Wang Y, Edens N, Pereira SL, Always SE. $\beta$-Hydroxy- $\beta$-methylbutyrate reduces myonuclear apoptosis during recovery from hind limb suspension-induced muscle fiber atrophy in aged rats. Am J Physiol Regul Integr Comp Physiol. 2011;301(3):701-15.

19. Krzysztof $D$, Jan J. The efficacy of a $\beta$-hydroxy- $\beta$-methylbutyrate supplementation on physical capacity, body composition and biochemical markers in elite rowers: A randomised, double-blind, placebo-controlled crossover study. J Int Soc Sports Nutr. 2015;12(31):1-11.

20. Daré LR, Dias DV, Rosa Junior GM, Bueno CRS, Buchaim RL, Rodrigues AC, et al. Effect of b-hydroxy-bmethylbutyrate in masticatory muscles of rats. J Anat. 2015;226(1):40-6.

21. Wheatley SM, El-Kadi SW, Suryawan A, Boutry C, Orellana RA, Nguyen HV. Protein synthesis in skeletal muscle of neonatal pigs is enhanced by administration of $\beta$-hydroxy- $\beta$-methylbutyrate. Am J Physiol Endocrinol Metab. 2014;306(1):e91-9.

22. Davis TA, Fiorotto ML, Burrin DG, Reeds PJ, Nguyen HV, Beckett PR, et al. Stimulation of protein synthesis by both insulin and amino acids is unique to skeletal muscle in neonatal pigs. Am J Physiol Endocrinol Metab. 2002;282(4):880-90. 